J. Lake Sci. (湖泊科学) , 2018, 30(1): 183-191

DOI 10. 18307/2018. 0118

(c) 2018 by Journal of Lake Sciences

\title{
苏北骆马湖浮游植物群落结构及其水质生物评价”
}

\author{
彭 凯 ${ }^{1,2}$, 李太民 ${ }^{3}$, 刘 利 $^{3}$, 邹 伟 ${ }^{1,2}$, 吴天浩 ${ }^{1,2}$, 龚志军 ${ }^{1 * *}$ \\ (1: 中国科学院南京地理与湖泊研究所湖泊与环境国家重点实验室,南京 210008) \\ (2: 中国科学院大学,北京 100049) \\ $(3:$ 江苏省骆运水利工程管理处,宿迁 223800)
}

\begin{abstract}
摘 要: 为了解骆马湖浮游植物的群落结构及其水质健康状态, 于 2014 年对骆马湖浮游植物进行逐月野外调查研究. 共 鉴定出浮游植物 $7 门 71$ 种属, 其中蓝藻门和硅藻门最多, 其次为绿藻门. 全湖细胞丰度在 $1.52 \times 10^{6} \sim 7.89 \times 10^{6} \mathrm{cells} / \mathrm{L}$ 之 间, 全湖生物量在 $0.048 \sim 12.44 \mathrm{mg} / \mathrm{L}$ 之间. 非多维度量尺度分析结果显示, 骆马湖全湖浮游植物生物量从冬春季喜低温 的硅藻门为主演替到夏秋季喜高温的蓝藻门为主, 表明骆马湖浮游植物有着明显的季节演替规律. 与 20 世纪相比, 骆马 湖浮游植物优势种属有着很大的变化, 富营养化指示属隐藻、纤维藻、针杆藻、鱼腥藻、伪鱼腥藻等明显增多, 表明自 20 世 纪以来, 骆马湖富营养化程度正在加剧. 与邻近的洪泽湖、南四湖、高邮湖、邵伯湖和宝应湖相比, 骆马湖浮游植物细胞丰 度高于宝应湖, 但低于其他 4 个湖泊. 基于浮游植物的水质评价结果, 骆马湖目前处于从塞污带向 $\beta$-中污带过渡的状态, 富营养化程度轻于洪泽湖, 与南四湖部分湖区富营养化程度相似.
\end{abstract}

关键词: 浮游植物;群落演替;生物指标;骆马湖;指示种;富营养化;大运河

\section{Community structure of phytoplankton and bio-assessment of water quality in Lake Luo- ma, northern Jiangsu Province}

\author{
PENG Kai ${ }^{1,2}$, LI Taimin ${ }^{3},{\text { LIU } \text { Li }^{3}, \text { ZOU Wei }}^{1,2}$, WU Tianhao ${ }^{1,2}$ \& GONG Zhijun ${ }^{1 * *}$ \\ (1: State Key Laboratory of Lake Science and Environment, Nanjing Institute of Geography and Limnology, Chinese Academy \\ of Sciences, Nanjing 210008, P.R. China) \\ (2: University of Chinese Academy of Sciences, Beijing 100049, P.R.China) \\ (3: Luoyun Management Division, Suqian 223800, P.R.China)
}

\begin{abstract}
Phytoplankton was investigated monthly in Lake Luoma, northern Jiangsu Province from January to December of 2014 in order to study the structure of phytoplankton community and the bio-assessment of water quality. A total of 7 phyla, including 71 genera or species of phytoplankton were identified. Chlorophyta was the most abundance taxa and followed by Cyanophyta and Bacillariophyta. The phytoplankton abundance of the whole lake was ranged from $1.52 \times 10^{6}$ cells $/ \mathrm{L}$ to $7.89 \times 10^{6}$ cells $/ \mathrm{L}$, and the biomass was ranged from $0.048 \mathrm{mg} / \mathrm{L}$ to $12.44 \mathrm{mg} / \mathrm{L}$. Nonmetric multidimensional scaling analysis demonstrate that the phytoplankton structure has obvious seasonal succession pattern. Compared to the 20th century, dominant genera have changed obviously. For example, the indicator genera of eutrophication, such as Cryptomonas, Ankistrodesmus, Synedra, Anabaena and Pseudanabaena have increased significantly, which indicates the increasing eutrophication trend of Lake Luoma since the last 20th century. Lakes Nansi, Hongze, Shaobo, Baoying and Gaoyou are close to Lake Luoma and are all connected by the Grand Canal. Compared with the four nearby lakes, the phytoplankton abundance in Lake Luoma are higher than that in Lake Baoying. Based on the bio-assessment of water quality, Lake Luoma has been suffered a transform from oligosaprobic zone to $\beta$-mesosaprobic zone pollution, and its eutrophication degree is lower than that of Lakes Hongze, Shaobo, Gaoyou, and is similar with some zones of Lake Nansi.
\end{abstract}

Keywords: Phytoplankton; community succession; biological index; Lake Luoma; indicator species; eutrophication; Grand Canal

* 江苏省水利科技项目 (2015043) 和国家自然科学基金项目 (41671110,31270505) 联合资助. $2017-02-17$ 收稿; 2017-05-08 收修改稿. 彭凯(1990 ), 男, 硕士研究生; E-mail: 820295327@ qq.com.

** 通信作者; E-mail: zjgong@ niglas.ac.cn. 
骆马湖 $\left(34^{\circ} 00^{\prime} \sim 34^{\circ} 14^{\prime} \mathrm{N}, 118^{\circ} 04^{\prime} \sim 118^{\circ} 18^{\prime} \mathrm{E}\right)$ 是淮河流域第三大湖泊、江苏省第四大湖泊, 为宿迁、徐 州两市共辖, 地处徐州、连云港经济带中部, 交通便捷, 区位优势明显 ${ }^{[1]}$, 长 $27.0 \mathrm{~km}$, 最大宽 $20.0 \mathrm{~km}$, 平均宽 $9.63 \mathrm{~km}$, 面积 $260.0 \mathrm{~km}^{2}$, 容积 9.18 亿 $\mathrm{m}^{3}$, 汇水面积约 $1300 \mathrm{~km}^{2}$. 骆马湖北面通过运河与山东南四湖相连, 南 与洪泽湖相连, 继而与长江水系相通, 是典型的过水性湖泊, 人湖河流主要有沂河水系、南四湖水系和䂙苍 地区共 40 多条支流. 出流处有 3 处,一经嶂山闸人新沂河,一经皇河闸人中运河,一经洋河滩闸人六塘河 ${ }^{[2]}$. 骆马湖不仅是沂河、中运河洪水的主要调蓄湖泊, 也是宿迁、新沂两市的重要水源地, 又是国家南水北调东 线输水工程的主要调节水库之一 ${ }^{[3]}$. 由于非法采砂、围网养殖、污染物的大量排放、船舶污染等造成了湖面 萎缩、水质下降、生态环境恶化,使得骆马湖生态环境问题日益严重 ${ }^{[4]}$.

水环境的改变不仅会引起水质的变化, 也会改变水体中生物群落组成 ${ }^{[5]}$, 浮游植物作为水体中的初级 生产者, 与其生活水域的水质状况紧密相连, 优势种的变化可以客观地指示水质的变化 ${ }^{[6]}$. Villegas 等人提 出浮游植物可以作为生物指标来指示水质 ${ }^{[7]}$, 因为浮游植物的种群结构变化是水环境演变的直接后果之一. 由于能迅速响应水体环境变化, 且不同浮游植物对有机质和其他污染物的敏感性不同, 因而可以用藻类群 落组成来判断不同水域的水质状况和水体健康程度 ${ }^{[8]}$. 早在 2000 年, 欧盟水框架指令 (WFD) 就将浮游植物 纳人河流湖泊监测范围 ${ }^{[9]}$. 一般来说, 由浮游植物来评价水质富营养化程度的常见方法有指示种法与种类 多样性指数法.

近年来众多研究对骆马湖水质及富营养化程度进行了评价, 得出骆马湖处于中富营养化水平 ${ }^{[10-11]}$. 但 这些研究大多是基于水质化学指标进行富营养化评价, 对于骆马湖浮游植物群落结构及其富营养化评价的 报道不多 ${ }^{[2-13]}$. 本文旨在通过对骆马湖采样调查, 分析浮游植物群落结构并进行水质生物学评价, 以期为骆 马湖生态环境保护与管理提供数据支持.

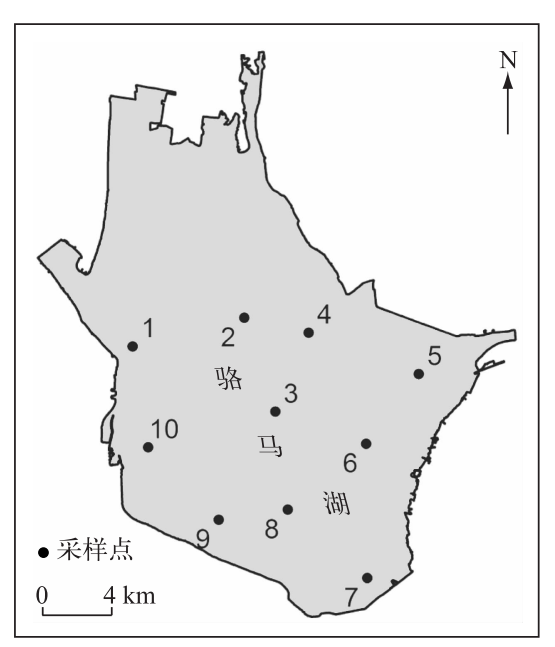

图 1 骆马湖采样点分布

Fig. 1 Spatial distribution of sampling sites in Lake Luoma

\section{1 材料与方法}

\section{1 采样点的布设与样品采集}

考虑到骆马湖的形状、围网养殖、采砂、人湖出湖河流等情 况在骆马湖设置了 10 个采样点 (图 1), 2014 年 1-12 月逐月 进行水质和浮游植物采样. 每个采样点分表层和中层采样, 混 合后每个水样保留 $1000 \mathrm{ml}$, 然后立即加人鲁哥试剂固定用以分 析浮游植物样品, 在稳定的试验台上固定 $24 \sim 36 \mathrm{~h}$, 用细小虹吸 管移出上清液, 最后定容到 $30 \mathrm{ml}$. 取浓缩后的 $0.1 \mathrm{ml}$ 样品通过 显微镜放大 400 倍下鉴定浮游植物种类和计数; 计数方法为目 镜视野法, 一般随机计数 $30 \sim 50$ 个视野, 使得细胞数在 300 以 上. 由于浮游植物的比重接近 1 , 故可直接将浮游植物的体积换 算成生物量 (湿重), 即生物量为各自的丰度乘以各自的平均体 积, 单位为 $\mathrm{mg} / \mathrm{L}$, 单细胞的生物量主要根据浮游植物个体形状 测量而得. 本节实验主要参考《淡水浮游生物研究方法》 ${ }^{[14]}$.

\section{2 数据分析}

多样性指数常用的指标有 Shannon-Wiener 多样性指数 $\left(H^{\prime}\right)^{[15]}$ 、Pielou 均匀度指数 $(J)^{[16]}$ 和 Margalef 多样性指数

$(D)^{[6]}$. 其中 Shannon-Wiener 多样性指数对浮游植物群落结构物种数比较敏感, 对浮游植物多样性有着很 好的解释; Pielou 均匀度指数是浮游植物群落均匀度测度中较好的一种. 使用两种指数同时对骆马湖富营养 化进行生物学评价,水体富营养化及其评价标准可参考文献 [17].

非度量多维标度分析 (non-metric multidimensional scaling, NMDS) 是基于对象间顺序关系而进行的排 序, 它可以基于任何距离的矩阵对样方进行排序 ${ }^{[18]}$. NMDS 的思想是使用尽可能少的排序轴 (通常是 $2 \sim 3$ 轴）充分展示主体间的相对位置, 运用在浮游植物生态学中即通过尽可能少的排序轴展示浮游植物不同种 类间的相对关系 ${ }^{[19]}$. 相对主成分分析, NMDS 能够更好地处理 0 值问题. 本文作图使用软件 R-3.2 完成. 
NMDS 分析由程序包 Vegan 实现.

\section{2 结果与分析}

\section{1 浮游植物的群落结构}

2.1 .1 浮游植物的种类 本次调查的定量样品中, 鉴定到包括硅藻门、隐藻门、绿藻门、蓝藻门、甲藻门、金藻 门和黄藻门共计 71 种属. 其中硅藻门 15 种属, 隐藻门 4 种属, 绿藻门 34 种属, 蓝藻门 10 种属, 裸藻门 5 种 属, 甲藻门、金藻门和黄藻门各 1 种属. 本次调查鉴定到的绿藻门种属数最多, 优势属 (括号内数字为优势 度) 为栅藻 (Scenedesmus, 0.03 )、纤维藻 (Ankistrodesmus, 0.01$)$ 和丝藻 (Ulothrix , 0.026) ; 硅藻门种属数次之, 优 势属有针杆藻 (Synedra , 0.04) ; 蓝藻门优势属有伪鱼腥藻 (Pseudanabaena , 0.09) 和平裂藻 (Merismopedia spp. 0.05 ) ; 隐藻门优势属为隐藻属 (Cryptomonas, 0.01 ) 等.

从生物量来看, 隐藻门优势属有隐藻属 (Cryptomonas, 0.03 ), 绿藻门优势属有纤维藻 (Ankistrodesmus, 0.11 ), 金藻门有雉囊藻属 (Dinobryon, 0.03), 硅藻门有针杆藻属 (Synedra, 0.18) 和脆杆藻属 (Fragilaria, $0.02)$.

2.1.2 浮游植物的空间分布 全湖浮游植物丰度呈现出西北低东南高的特点 (图 2), 其中 $6^{\#}$ 点位丰度最高, 约为 $7.89 \times 10^{6} \mathrm{cells} / \mathrm{L}$, 其优势属为绿藻门的栅藻属, 硅藻门的针杆藻属, 蓝藻门的鱼腥藻属、伪鱼腥藻属和 平裂藻属; $1^{\#} 、 9^{\#} 、 10^{\#}$ 点位丰度较低. 从各门类来看, $1^{\#}$ 和 $2^{\#}$ 点位绿藻占优势, 超过 $50 \%$; 而 $3^{\#} \sim 8^{*}$ 点位以蓝 藻为主, 超过 $50 \%$. 从丰度上来看, 蓝藻门是骆马湖的优势门类. 从各点位来看, 骆马湖全年浮游植物生物量 没有明显差异,各点位均在 $1.2 \mathrm{mg} / \mathrm{L}$ 左右, 其中 $7^{\#} 、 9^{\#}$ 点位较高. 但是不同门类生物量的全湖分布有着明显 的差异: $7^{\#} 、 9^{\#}$ 点位硅藻生物量明显多于其他点位 $; 5^{\#} 、 7^{\#}$ 点位的绿藻生物量较其他点位高; $6^{\#}$ 点位蓝藻生物 量较高. 相较于其他门类, 蓝藻丰度较多但是生物量较低 (图 3).
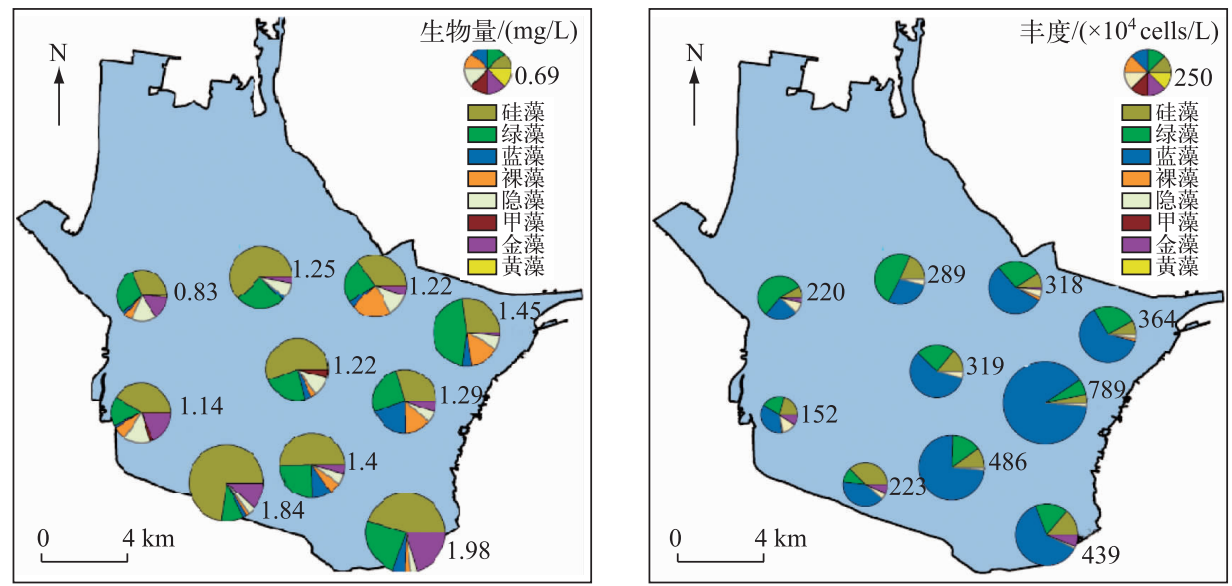

图 2 骆马湖浮游植物生物量与丰度的空间分布

Fig. 2 Spatial distribution patterns of phytoplankton biomass and abundance in Lake Luoma

2.1.3 浮游植物的时间分布 本次调查中, 浮游植物丰度呈现单峰分布, 峰值出现在 8 月. 总体来看, 各月份 浮游植物丰度在 $1.52 \times 10^{6} \sim 7.89 \times 10^{6} \mathrm{cells} / \mathrm{L}$ 之间, 蓝藻门丰度占总丰度的 $60.70 \%$, 为绝对的优势门, 其次为 绿藻门和硅藻门, 分别占 $21.13 \%$ 和 $17.50 \% .1-3$ 月份优势门类为硅藻, 其中优势度较高的属为针杆藻属和 脆杆藻属. 但从 5 月开始, 蓝藻和绿藻开始大量增加, 并在 8 月丰度达到峰值, 之后逐渐开始下降. 从全湖来 看, 骆马湖全年浮游植物丰度平均值为 $3.60 \times 10^{6} \mathrm{cells} / \mathrm{L}$ ( 图 3).

本次调查中, 浮游植物的生物量差异较大, 全年呈明显的双峰分布, 峰值分别出现在 2 和 7 月. 时间上, 最低生物量出现在 11 月的 $9^{\#}$ 点位, 为 $0.048 \mathrm{mg} / \mathrm{L}$, 最高生物量出现在 2 月的 $9^{\#}$ 点位, 为 $12.44 \mathrm{mg} / \mathrm{L} .1-3$ 月 由于硅藻数量较多, 生物量较高, 而 $5 、 6$ 月由于温度逐渐增加导致硅藻数量下降, 但是温度又不能满足蓝藻 


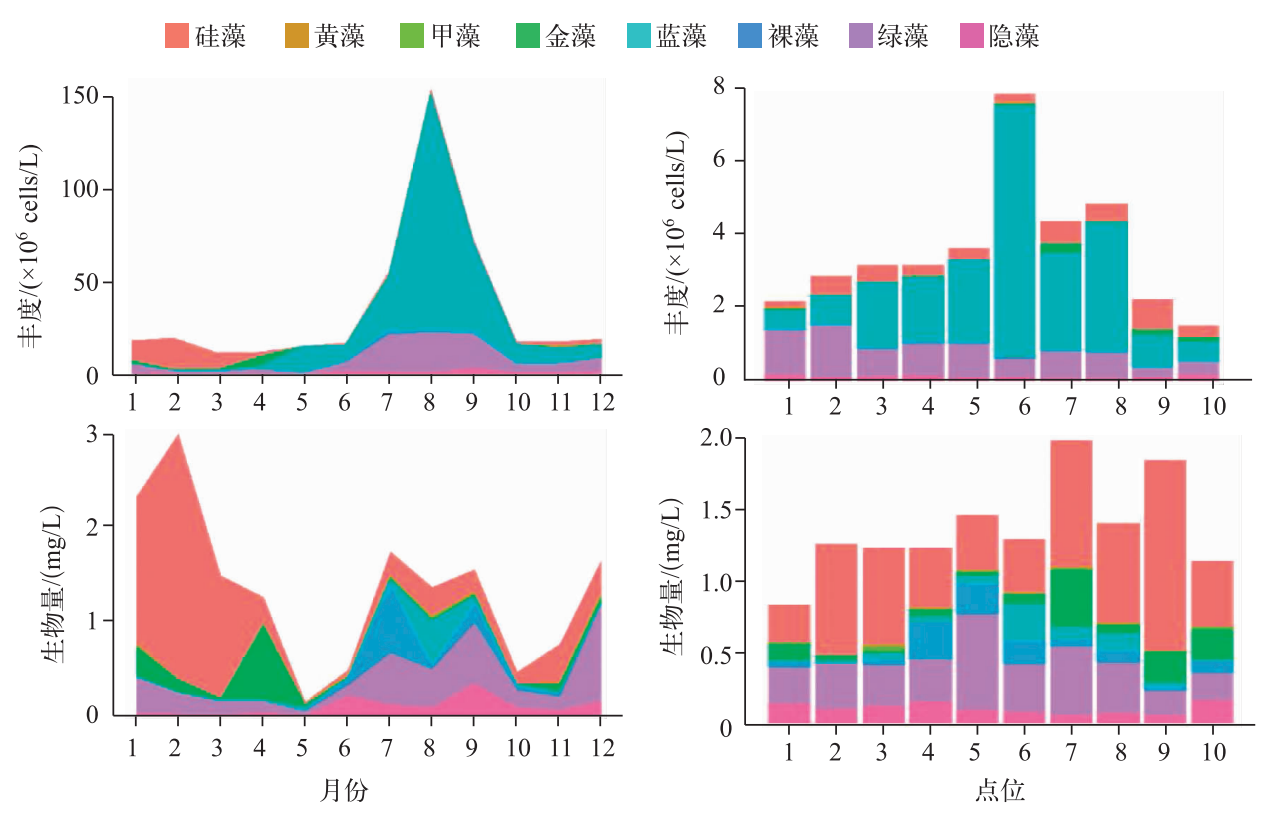

图 3 骆马湖浮游植物丰度与生物量分布

Fig.3 Abundance and biomass of phytoplankton in Lake Luoma

大量繁殖的需求, 所以生物量出现明显下降, 7、8 月进人夏季, 温度较高, 使得蓝藻、绿藻等喜高温种类大量 生长, 生物量又开始上升, 10 月由于温度逐渐下降, 蓝藻数量开始下降, 生物量随之下降, 随后, 随着温度的 进一步下降, 硅藻逐渐占优势,生物量又开始上升(图 3).

2.1.4 浮游植物群落的 NMDS 分析 采用 NMDS 分析对骆马湖浮游植物群落进行排序, 选取优势度前 20 的 物种丰度数据基于 Bray-Curtis 矩阵 ${ }^{[20]}$ 进行 NMDS 排序, 在二维空间上的应力值大于 0.2 , 所以采用 3 轴后的 NMDS 分析应力值, 为 0.1526 , 达到理想水平. 前两轴的 NMDS 分析如图 4 所示, 非线性拟合系数为 0.977 , 表 明排序结果可靠. 从图 $4 \mathrm{a}$ 可以看出, 4 个季节分化较明显, 而夏季的蓝藻和绿藻细胞数量增加迅速, 所以夏 季蓝藻门和绿藻门的物种离夏季点位近. 图 $4 \mathrm{~b}$ 中的点代表每个月份的点位平均值, 物种所在位置表明离此 区域较近的点位, 该物种数目可能较多, 冬季温度较低, 所以硅藻门的脆杆藻和针杆藻位于冬季月份附近线 条代表浮游植物群落的四季演替.

\section{2 骆马湖水质生物学评价}

从全年平均生物量来看, 硅藻门所占比例为 $45 \% \pm 14 \%$, 绿藻门比例为 $25 \% \pm 8.9 \%$, 蓝藻门所占比例很 低. 由 $J 、 H^{\prime}$ (图 5) 及各门类生物量占比可推断骆马湖处于从寡污带向 $\beta$-中污带过渡的状态. 但是不同季节、 点位之间存在差别.

春季浮游植物全湖平均 $H^{\prime}$ 为 1.03 , 基本属于中度污染; 优势属为针杆藻属, 属于富营养化指示物种. $5^{\#}$ 点位的 $H^{\prime}$ 最高 $(1.50), 2^{\#}$ 点位最低 (0.43), 其他点位则在 1.00 附近. $2^{\#}$ 点位优势种是针杆藻属, 属富营养化 指示物种, 说明该点位可能春季污染比较严重, 其他点位则基本处于中度污染状态. 春季 $H^{\prime}$ 与 $J$ 高度相关, 说明春季多样性高低主要取决于物种之间生物量相对比例.

夏季浮游植物全湖平均 $H^{\prime}$ 为 1.80 , 比春季略有上升, 不同点位在 $1.50 \sim 2.00$ 之间波动. 优势属为裸藻属 和伪鱼腥藻属, 同样处于中度污染、富营养化状态. 相比于春季, 夏季的丰富度有明显提高, $J$ 值变化不大; 但 是多样性指数同样主要受 Pielou 均匀度指数影响.

秋季浮游植物全湖平均 $H^{\prime}$ 为 1.80 , 不同点位在 $1.30 \sim 2.30$ 之间波动, 与夏季变化不大. 物种多样性指数 主要受物种丰富度影响. 多样性指数显示秋季骆马湖主要为中度污染. 优势属为纤维藻和隐藻, 同样是富营 养化指数物种. 多样性指数最低的点位为 $9^{\#}$, 最高的为 $7^{\#}$. 

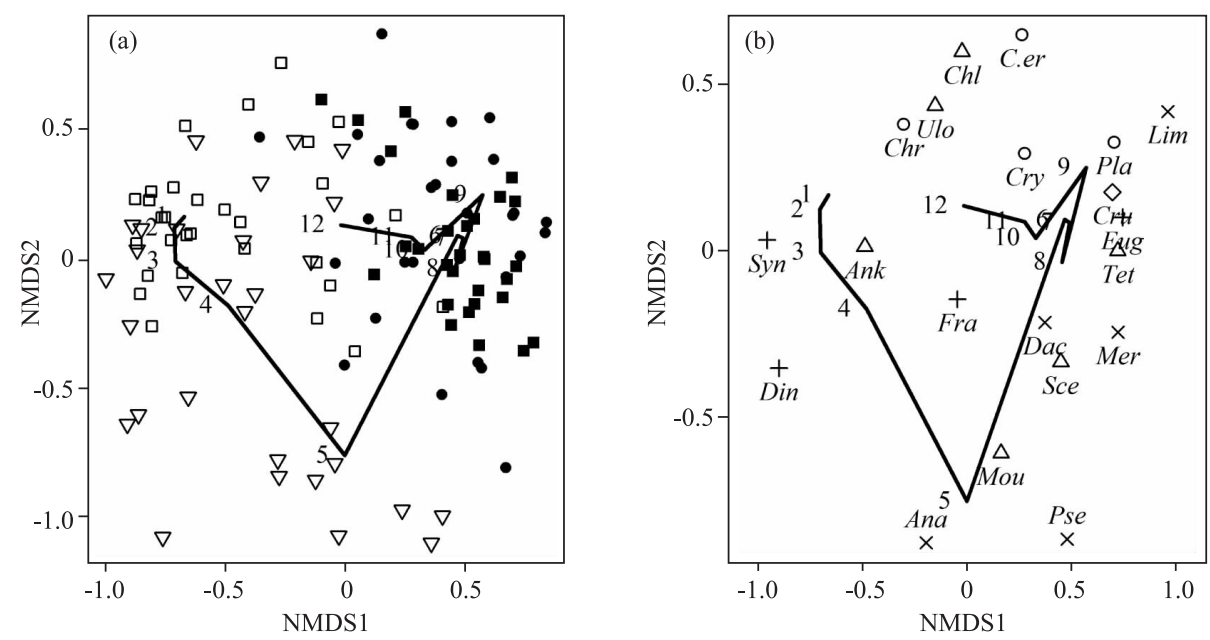

图 4 NMDS 样本 (a) 与物种 (b) 得分排序图 ( $\nabla$ 表示春季、表示夏季、・表示秋季、 $\square$ 表示冬季;

$C r y$ 为隐藻、C.er 为啮蚀隐藻、Chro 为蓝隐藻、 $M o u$ 为转板藻、Scen 为栅藻、Chl 为小球藻、

$A n k$ 为纤维藻、Tet 为四角藻、Ulo 为丝藻、 $C r u$ 为十字藻、 $I n$ 为锥囊藻、Syn 为针杆藻、 $F r a$ 为脆杆藻、

$E u g$ 为裸藻、 $A n a$ 为鱼腥藻 $、 P s e$ 为伪鱼腥藻 $、 \mathrm{Mer}$ 为平裂藻、 $D a c$ 为蓝纤维藻、 $L i m$ 为湖丝藻、 $P l a$ 为颤藻; $1 \sim 12$ 表示每月样方得分的平均值, 线条表示浮游植物的季节变化)

Fig.4 Bio-ordination of samples (a) and species (b) scores with NMDS

冬季浮游植物全湖平均 $H^{\prime}$ 下降到 1.10 , 主要是丰富度下降显著. 最高值出现在 $1^{\#}$ 点位 $\left(H^{\prime}=1.40\right)$ 和 $10^{\#}$ 点位 $\left(H^{\prime}=1.35\right)$, 最低值出现在 $6^{\#}$ 点位和 $9^{\#}$ 点位. 冬季主要优势属为针杆藻属, 说明冬季骆马湖同样处于中 度污染、富营养化状态.
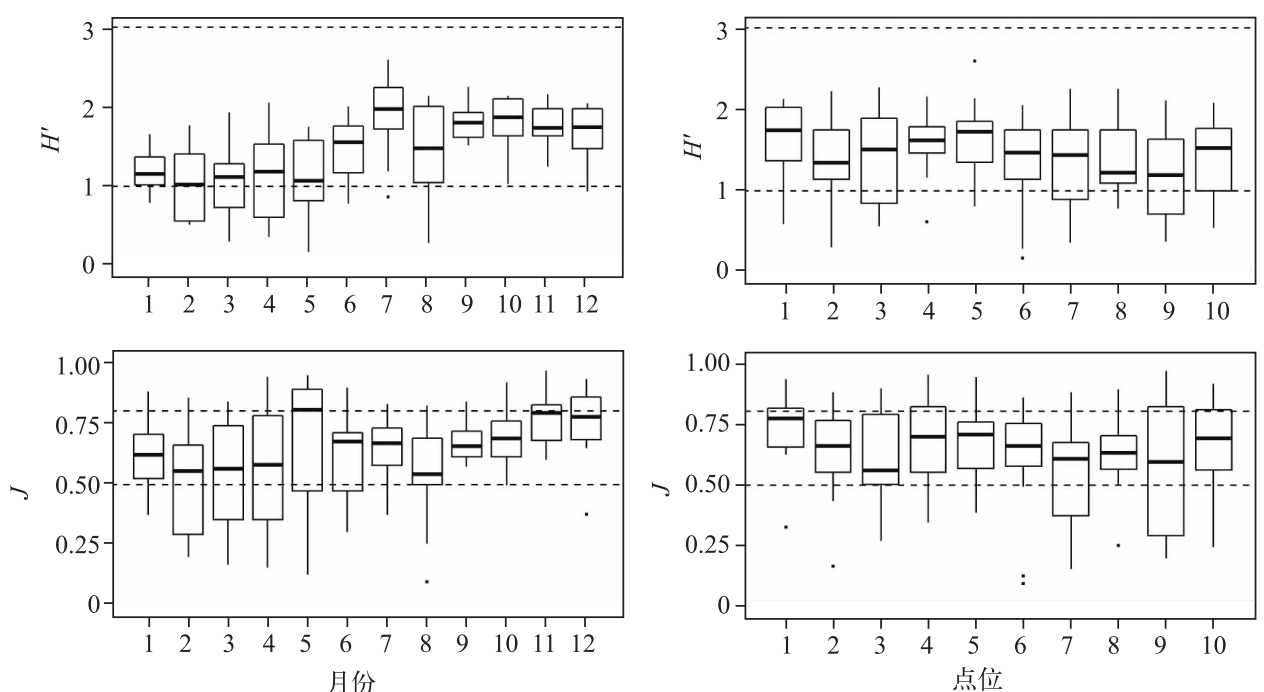

图 5 骆马湖浮游植物 Shannon-Wiener 多样性指数和 Pielou 均匀度指数的分布

Fig.5 Distribution of Shannon-Wiener index and Pielou index of phytoplankton in Lake Luoma 


\section{3 讨论}

\section{1 骆马湖浮游植物群落与演变}

根据《中国湖泊志》记载, 20 世纪骆马湖鉴定到浮游植物 6 门 59 属, 以针杆藻、菱形藻、十字藻、直链藻、 孟氏藻、丝藻、小球藻、盘星藻、微胞藻和色球藻为优势种属 ${ }^{[2]}$. 本次调查共鉴定到浮游植物 7 门 71 种属, 其 中隐藻、蓝隐藻、栅藻、纤维藻、丝藻、雉囊藻、针杆藻、鱼腥藻、伪鱼腥藻、平裂藻为优势种. 两次调查相比, 本 次所调查到的浮游植物种类有所增加. 就优势种来说, 两次调查浮游植物优势种变化较大, 仅针杆藻、丝藻 为共同优势种. 从 20 世纪所调查的结果来看, 菱形藻、针杆藻、直链藻、丝藻都是中一富营养型水体指示种, 十字藻和小球藻为富营养型水体指示种, 本次调查中, 丝藻、针杆藻为中一富营养水体指示种, 而隐藻、纤维 藻、针杆藻、鱼腥藻、伪鱼腥藻为富营养化水体指示种. 由此可以从一定程度上说明, 相较于 20 世纪, 骆马湖 富营养化已经加剧. 2001-2005 年的水质数据也表明骆马湖富营养化程度有逐年加重的趋势 ${ }^{[21]}$.

\section{2 与临近湖泊浮游植物群落结构的比较}

临近的南四湖、洪泽湖、高邮湖、宝应湖、邵伯湖通过运河与骆马湖相连, 这 6 个湖泊的浮游植物优势种 属如表 1 所示 ${ }^{[22-24]}$. 相较于北部的骆马、洪泽、南四湖, 这 3 个湖泊浮游植物 $J$ 和 $H^{\prime}$ 均较高. 虽然以上 6 个湖

表 1 骆马湖、洪泽湖、南四湖、高邮湖、宝应湖和邵伯湖浮游植物优势种属的对比

Tab.1 Contrast of phytoplankton dominant genera or species in Lakes Luoma,

Hongze, Nansi, Gaoyou, Baoying and Shaobo

\begin{tabular}{|c|c|c|c|c|c|}
\hline 湖泊 & 种类数 & 优势种属 & $\begin{array}{c}\text { 密度/ } \\
\left(\times 10^{4} \text { cells/L }\right)\end{array}$ & $\begin{array}{l}\text { 生物量/ } \\
(\mathrm{mg} / \mathrm{L})\end{array}$ & 多样性指数 \\
\hline 南四湖 & $\begin{array}{l}8 \text { 门 } 117 \text { 种属 ( 绿 } \\
\text { 藻门 } 38.9 \% \text { 、蓝藻 } \\
\text { 门 } 17.6 \% \text { 、硅藻门 } \\
15.9 \%)\end{array}$ & $\begin{array}{l}\text { 小球藻 (Chlorella spp.)、色球藻 ( Chroococcus } \\
\text { spp.)、席藻 ( Phormidium spp.)、小环藻 (Cy- } \\
\text { clotella spp.)、针杆藻 (Synedra spp.)、啮蚀隐 } \\
\text { 藻 (Cryptomonas erosa) }\end{array}$ & $\begin{array}{c}33 \sim 2434 \\
548 \text { (均值) }\end{array}$ & $\begin{array}{c}0.46 \sim 25.9 \\
6.45 \text { (均值) }\end{array}$ & $\begin{array}{c}H^{\prime}: 0.84 \sim 2.68 \\
1.76 \text { (均值) }\end{array}$ \\
\hline 骆马湖 & $\begin{array}{l}7 \text { 门 } 71 \text { 种属 (绿 } \\
\text { 藻门 } 47.9 \% \text { 、硅藻 } \\
\text { 门 } 21.1 \% \text { 、蓝藻门 } \\
14.1 \% \text { ) }\end{array}$ & $\begin{array}{l}\text { 隐藻 ( Cryptomonas spp.)、蓝隐藻 ( Chroomonas } \\
\text { spp.)、栅藻 ( Scendesmus spp.)、纤维藻 (Ankis- } \\
\text { trodesmus spp.)、丝藻 ( Ulothrix spp.)、雉囊藻 } \\
\text { (Dinobryon spp.)、针 杆 藻、鱼 胜 藻 } \\
\text { (Anabaena } \text { spp.) }\end{array}$ & $\begin{array}{c}152 \sim 789 \\
360 \text { (均值) }\end{array}$ & $\begin{array}{c}0.048 \sim 12.44 \\
1.2 \text { (均值) }\end{array}$ & $\begin{array}{c}H^{\prime}: 0.43 \sim 1.50 \\
1.03 \text { (均值) } \\
J: 0.10 \sim 0.96 \\
0.63 \text { (均值) }\end{array}$ \\
\hline 洪泽湖 & $\begin{array}{l}8 \text { 门 } 101 \text { 属 } 201 \text { 种 } \\
\text { (绿藻门 } 45.8 \% \text { 、 } \\
\text { 蓝藻门 } 13.9 \% \text { 、硅 } \\
\text { 藻门 } 21.4 \% \text { ) }\end{array}$ & $\begin{array}{l}\text { 小球藻、集球藻 ( Palmellococcus } \text { spp.) 、游丝藻 } \\
\text { (Planktonema } \mathrm{sp} \text { ) 、细链丝藻 (Hornidium sub- } \\
\text { tile)、细丝藻 ( Sinocylindra spp.)、惠氏微囊藻 } \\
\text { (Microcystis wesenbergii)、小环藻、尖尾蓝隐 } \\
\text { (Chroomonas acuta)、啮蚀隐藻 }\end{array}$ & $172 \sim 3633.3$ & $\begin{array}{c}3.08 \pm 1.9 \\
(\text { 北部) } \\
2.75 \pm 1.43 \\
(\text { 西部) } \\
2.34 \pm 1.52 \\
\text { (东部) }\end{array}$ & $\begin{array}{c}H^{\prime}: 3.17 \sim 4.74 \\
3.92 \text { (均值) } \\
D: 0.51 \sim 0.73 \\
0.63 \text { (均值) }\end{array}$ \\
\hline 邵伯湖 & $\begin{array}{l}8 \text { 门 } 66 \text { 属 } 156 \text { 种 } \\
\text { (绿藻门 } 45.6 \% \text { 、 } \\
\text { 蓝藻门 } 13.2 \% \text { 、硅 } \\
\text { 藻门 } 20.6 \% \text { ) }\end{array}$ & $\begin{array}{l}\text { 小球藻、尖尾蓝隐藻、卷曲纤维藻 (Ankistro- } \\
\text { desmus convootus)、菱形肋 缝藻 (Frustulia } \\
\text { rhomboids) ( 以丰度计)／小环藻、尖尾蓝隐 } \\
\text { 藻、巨颤藻 (Oscillatoria princeps) ( 以生物量 } \\
\text { 计) }\end{array}$ & $\begin{array}{l}525.05 \\
\text { (均值) }\end{array}$ & 4.46 (均值) & $\begin{array}{l}H^{\prime}:>3.00 \\
J:>0.70 \\
\text { (宝应湖、邵伯 } \\
\text { 湖、高邮湖 } \\
\text { 较为接近) }\end{array}$ \\
\hline 宝应湖 & $\begin{array}{l}8 \text { 门 } 61 \text { 属 } 136 \text { 种 } \\
\text { (绿藻门 } 44.2 \% \text { 、 } \\
\text { 蓝藻门 } 13.5 \% \text { 、硅 } \\
\text { 藻门 } 21.8 \% \text { ) }\end{array}$ & $\begin{array}{l}\text { 尖尾 蓝 隐 藻、小 球 藻、小 形色 球 藻 } \\
\text { (Chroococcus minor)、栅藻( 以丰度计)/双头 } \\
\text { 针杆藻 (Synedra amphicephal)、尖尾蓝隐藻、 } \\
\text { (以生物量计) }\end{array}$ & 249.6(均值) & 1.728 (均值) & \\
\hline 高邮湖 & $\begin{array}{l}8 \text { 门 } 71 \text { 属 } 153 \text { 种 } \\
\text { (绿藻门 } 40.5 \% \text { 、 } \\
\text { 蓝藻门 } 14.4 \% \text { 、硅 } \\
\text { 藻门 } 22.9 \% \text { ) 种 }\end{array}$ & $\begin{array}{l}\text { 小环藻、卷曲纤维藻、尖尾蓝隐藻、湖泊伪鱼 } \\
\text { 腥藻 (Pseudanabaena limnetica)（以丰度 } \\
\text { 计)/颗粒直链藻 (Melosira granulata)、冰岛 } \\
\text { 直链 藻 ( Melosira islarica) 、尖 针 杆 藻 } \\
\text { (Synedra acusvar) ( 以生物量计) }\end{array}$ & 560.45 (均值) & 4.6 (均值) & \\
\hline
\end{tabular}


泊浮游植物种类有所不同, 但是都以绿藻门、蓝藻门、硅藻门为主, 其中绿藻门种类最多. 本次调查中, 骆马 湖全湖细胞丰度以及平均值均低于南四湖、洪泽湖、邵伯湖以及高邮湖, 但是略高于宝应湖, 生物量也是如 此, 这与前人的研究结果相似 ${ }^{[25]}$. 以上 6 个湖泊中, 高邮湖、宝应湖、邵伯湖的 $H^{\prime}$ 和 $J$ 最高, 而洪泽湖高于骆 马湖与南四湖. 另外, 水质评价也表明, 洪泽湖处于富营养化水平 ${ }^{[26]}$; 除了南阳湖为中度富营养化状态外, 南四湖其他 3 个湖区均处于轻度富营养化水平 ${ }^{[21]}$; 骆马湖处于中营养水平 ${ }^{[27]}$; 宝应湖为中营养状态; 邵伯 湖与高邮湖为轻度富营养状态.

\section{3 骆马湖水质生物学评价}

基于藻类的湖泊富营养化生物学评价有多种方法 ${ }^{[28-29]}$, 本文选择使用最为广泛的指示种法和多样性指 数法对骆马湖富营养化进行评价 ${ }^{[30]}$. 其中 $H^{\prime}$ 在 $1.00 \sim 2.50$ 之间, 表明骆马湖处于 $\beta$-中污带; 而 $J$ 在 $0.50 \sim$ 0.80 之间, 表明骆马湖水体为清洁-寡污型. 骆马湖不同区域富营养化水平相差不大, 但是不同月份之间差 别较明显, 3、4 月富营养化程度较严重, 骆马湖是过水性湖泊, 水质的变化受上游来水的影响较大, 而春季是 多雨的季节, 加上春播施肥量增大, 农业面源污染增加, 水质富营养化程度加深. Shannon-Wiener 多样性指数 和 Pielou 均匀度指数评价结果有一定的差别. 有研究结果表明, 两种指数有着很好地吻合度, 并且能对水质 进行合理的评价 ${ }^{[31-32]}$, 也有研究表明两种指示结果存在差异 ${ }^{[33-34]}$. 但是结合浮游植物优势种的结果可得出 骆马湖总体上处于从寡污带向 $\beta$-中污带过渡的状态.

申霞等利用富营养状态指数法并选取叶绿素 $\mathrm{a} 、$ 透明度、总氮、总磷、高锰酸盐指数等对骆马湖进行水质 评价, 表明骆马湖处于中营养化状态, 离富营养化较接近 ${ }^{[35]}$. 富营养化程度略高于本文利用浮游植物的评 价结果, 这可能是因为骆马湖为过水性湖泊, 浮游植物丰度受水流速度影响较大 ${ }^{[36]}$. 本次调查中, 骆马湖浮 游植物丰度与临近的南四湖、洪泽湖、高邮湖、宝应湖、邵伯湖相比, 仅高于邵伯湖. 流速较高的水体不利于 比重较低的细胞停留, 一般在流水系统中蓝藻门与硅藻门较多 ${ }^{[37]}$. 本次调查中, 骆马湖浮游植物丰度从北 向南逐渐降低, 群落组成中, 北部地区比重较轻的蓝藻门所占比例较低, 这是由于骆马湖来水主要为上游的 沂河水系, 黾河闸由于常年处于关闭状态, 出水以新沂河为主, 南部地区水流相对较为平缓. 以蓝藻门为主 并且占据优势的比重较轻的种类在群落中的数目减少, 导致计算 $H^{\prime}$ 时各物种间的均匀性增加, 从而造成 $H^{\prime}$ 偏高, 样品中的种类总数减少, $J$ 同时也会偏大, 并且幅度增加更大. 这也解释了本文中 $H^{\prime}$ 高于 $J$ 的结果. 而 从骆马湖不同点位的多样性指数分布来看, 北部 $1^{\#} \sim 5^{\#}$ 点位浮游植物多样性指数略高于南部湖区的 5 个点 位. 依照水化学指标进行富营养化评价时, 由于其具有瞬时性, 不能很好地反映湖泊健康状况, 因此对生物 与水化学指标进行综合评价才能得到更加可信和全面的结果 ${ }^{[38]}$.

致谢: 感谢江苏省骆运水利工程管理处在野外采样中的帮助.

\section{4 参考文献}

[ 1 ] Wan L, Xu DL, Gao MX et al. Effect of marcrophytes on nitrogen and phosphorus in Luoma Lake. Chinese Journal of Environmental Engineering, 2012, 6: 3579-3584. [万蕾, 徐德兰, 高明侠等. 大型水生植物对骆马湖氮、磷元素的影响. 环境工程学报, 2012, 6: 3579-3584.]

[2] Wang SM, Dou HS eds. Lakes in China. Beijing: Science Press, 1998: 281-282. [王苏民, 窦鸿身. 中国湖泊志. 北 京: 科学出版社, 1998: 281-282.]

[ 3 ] Xu DL, Wan L, Gao MX et al. Seasonal variations of nitrogen and phosphorus content and alkaline phosphatase activity in sediment in eastern shore of Luoma Lake, China. Journal of Agro-Environment Science, 2012, 31: 1387-1392. [徐德兰, 万蕾, 高明侠等. 骆马湖东部沉积物中氮磷含量和碱性磷酸酶活性季节变化. 农业环境科学学报, 2012, 31: 1387-1392.]

[ 4 ] Ye L. The Environment problems and countermeasures of Luoma Lake. Pollution Control Technology, 2015: 87-88. [叶玲. 骆马湖面临的环境问题和保护对策. 污染防治技术, 2015: 87-88.]

[ 5 ] Stocker TF, Qin D, Plattner GK et al. Climate Change 2013: The physical science basis. Contribution of Working Group I to the Fifth Assessment Report of IPCC the Intergovernmental Panel on Climate Change. Computational Geometry, 2014, 18(2): 95-123.

[ 6 ] Gao SR, Pan LJ, Sun FY et al. Assessment on the pollution and eutrophication of environmental water by hydroblologic. 
Environmental Science and Management, 2006, 31: 174-176. [高世荣, 潘力军, 孙风英等. 用水生生物评价环境水体 的污染和富营养化. 环境科学与管理, 2006, 31: 174-176. ]

[ 7 ] Villegas I, Giner GD. Phytoplankton as a biological indicator of water quality. Water Research, 1973, 7: 479-487. DOI: 10.1016/0043-1354 ( 73 ) 90028-6.

[ 8 ] Spatharis S, Roelke DL, Dimitrakopoulos PG et al. Analyzing the (mis) behavior of Shannon index in eutrophication studies using field and simulated phytoplankton assemblages. Ecological Indicators, 2011, 11: 697-703. DOI: 10.1016/j. ecolind.2010.09.009.

[ 9 ] Directive W. DIRECTIVE 2000/60/EC of the European Parliament and of the Council of 23rd October 2000 establishing a framework for community action in the field of water policy. Pediatric Radiology, 2000, 22 : 231-235.

[10] Cui DC, Hu F. Ecological restoration of Luoma Lake. Journal of Anhui Agri Sci, 2009, 37: 8131-8133. [崔德才, 胡锋. 骆马湖生态修复. 安徽农业科学, 2009, 37: 8131-8133.]

[11] Ren RL, Liu MS, Zhang JS et al. Self-purification ability of a water-carrying lake. Chinese Journal of Ecology, 2007, 26: 1222-1227. [任瑞丽, 刘茂松, 章杰明等. 过水性湖泊自净能力的动态变化. 生态学杂志, 2007, 26: 1222-1227.]

[12] Ren Y. Phytoplankton community characteristics and driving environment factors of regulating lakes in the east route of South-to-North Water Diversion Project[Dissertation]. Jinan: Shandong University, 2016. [任颖. 南水北调东线调蓄湖 泊浮游藻类群落特征与环境驱动因子 [学位论文]. 济南: 山东大学, 2016.]

[13] Zhang XM, Li C, Li Q. Investigation of planktonic algae and water quality assessment in Luoma Lake. Harnessing the Huaihe River, 2016，(1) : 29-30. [张小明, 李超, 李倩. 骆马湖浮游藻类调查与水质评价. 治淮, 2016, (1) : 29-30.]

[14] Zhang ZS, Huang XF eds. Research methods of freshwater plankton. Beijing: Science Press, 1991. [章宗涉, 黄祥飞. 淡 水浮游生物研究方法. 北京: 科学出版社, 1991.]

[15] Shannon CE, Weaver W, Hajek B et al eds. The mathematical theory of communication. Illinois: University of Illinois Press, 1998: 144.

[16] Pielou EC ed. Ecological diversity. New York: Wiley, 1975.

[17] Gao Y, Ci HX, Qi SC et al. Seasonal changes of phytoplankton and assessment of water quality in four tributaries of Yi River. Research of Environmental Sciences, 2009, 22(2) : 176-180. [ 高远, 慈海金金, 元树财等. 沂河 4 条支流浮游植 物多样性季节动态与水质评价. 环境科学研究, 2009, 22(2): 176-180.]

[18] Borcard D, Gillet F, Legendre P. Numerical ecology with R. Matisse, 2011, 77: 332-334. DOI: 10.1007/978-1-44197976-6.

[19] Deng JM, Tang XM, Shao KQ et al. Application of NMDS to analysis of phytoplankton community: A case study of Qingshui Rive. Journal of Ecology and Rural Environment, 2016, 32:150-156. [邓建明, 汤祥明, 邵克强等. 非度量多维 标度在亲水河浮游植物群落分析中的应用. 生态与农村环境学报, 2016, 32: 150-156.]

[20] Bray JR, Curtis JT. An ordination of the upland forest communities of southern Wisconsin. Ecological Monographs, 1957, 27: 325-349. DOI: $10.2307 / 1942268$.

[21] Zhou YL. Study on wetland resources and ecological protection of Luoma Lake[Dissertation]. Nangjing: Nanjing Forestry University, 2007. [ 周亚琳. 骆马湖湿地资源调查及生态保护研究 [学位论文]. 南京: 南京林业大学, 2007.]

[22] Leng CM, Wang YN, Dong GC et al. Community structure characteristics and the seasonal variation of phytoplankton in Lake Nansi. Journal of Shandong Agricultural University: Natural Science Edition, 2014, (2): 193-197. [冷春梅, 王亚 楠, 董贯仓等. 南四湖浮游植物群落结构特征及季相变化. 山东农业大学学报: 自然科学版, 2014, (2): 193-197.]

[23] Shu FY, Liu YP, Zhao Y et al. Spatio-temporal distribution of TN and TP in water and evaluation of eutrophic state of Lake Nansi. Environment Science, 2012, 33: 3748-3752. [ 舒凤月, 刘玉配, 赵颖等. 南四湖水体氮、磷营养盐时空分 布特征及营养状态评价. 环境科学, 2012, 33: 3748-3752.]

[24] Xia T, Chen J, Long J et al. Characteristic analysis of eutrophication on lakes in Gaobao water resources division in Jiangsu Province. Environment Monitoring and Forewarning, 2016, 8: 40-45. [夏霆, 陈静, 龙健等. 江苏省高宝湖区湖泊群 富营养化特征分析. 环境监控与预警, 2016, 8: 40-45.]

[25] Tian JY, Tian J, Shen BZ et al. Phytoplankton distribution and diversity along the East Route of South-to-North Water Transfer Projec. Shandong Science, 2008, 21: 28-34. [田家怡, 田静, 申保忠等. 南水北调东线工程输水沿线浮游植 物分布与多样性. 山东科学, 2008, 21: 28-34.] 
[26] Li DM, Zhang TQ, Tang SK et al. Abundance of toxic and non-toxic Microcystis sp. in Lake Hongze and correlation with environment factors. Environment Science, 2016, 37(2) : 573-579. DOI:10.13227/j.hjkx.2016.02.023. [李大命, 张肜 晴, 唐晟凯等. 洪泽湖有毒和无毒微囊藻丰度及其与环境因子之间的相关分析. 环境科学, 2016, 37 (2): 573-579. ]

[27] Jian B, Yang SJ, Zhao XL. Studies on pollution change characteristics and eutrophication assessment of Luoma Lake. Arid Environmental Monitoring, 2005, 19: 224-228. [姜波, 杨士建, 赵秀兰. 骆马湖水质变化特征及其富营养化评价. 干旱环境监测, 2005, 19: 224-228.]

[28] Karydis M, Tsirtsis G. Ecological indices: A biometric approach for assessing eutrophication levels in the marine environment. Science of the Total Environment, 1996, 186: 209-219. DOI: 10.1016/0048-9697(96)05114-5.

[29] Yang L, Wang XY, Sun CH et al. A Comparative study on evaluation methods of water eutrophication. 2013 Annual meeting of Chinese Society for Environment Sciences Proceedings (volume four), 2113. [杨龙, 王晓燕, 孙长虹等. 水体富 营养化评价方法比较研究. 中国环境科学学会学术年会论文集(第四卷). 2013.]

[30] Osowiecki A, Łysiak-Pastuszak E, Piątkowska Z. Testing biotic indices for marine zoobenthos quality assessment in the Polish sector of the Baltic Sea. Journal of Marine Systems, 2008, 74: S124-S132. DOI: 10.1016/j.jmarsys.2008.03.025.

[31] Fang K, Liu CQ, Yang J. Assessment on phytoplankton community and water quality of Baoding City watercourse in Daqing Basin. Journal of Hydroecology, 2013, 34: 25-31. [方慷, 刘存歧, 杨军. 大清河水系保定段城市河道浮游植 物群落结构及水质评价. 水生态学杂志, 2013, 34: 25-31.]

[32] Li FF, Dong F, Duan M et al. Phytoplankton community structure and water quality of Daliaohe river system in summer. Chinese Journal of Ecology, 2011, 30: 2489-2496. [李芳芳, 董芳, 段梦等. 大辽河水系夏季浮游植物群落结构特征 及水质评价. 生态学杂志, 2011, 30: 2489-2496.]

[33] Liu JD, Gu ZM, Yany YJ et al. Phytoplankton community structure and water quality assessment of Changzhao Reservoir, Zhejiang of East China. Chinese Journal of Ecology, 2012, 31: 2865-2871. [刘金殿, 顾志敏, 杨元杰等. 长诏水库浮 游植物群落结构及水质评价. 生态学杂志, 2012, 31: 2865-2871.]

[34] Wang JL, Liu DY, Gu BH et al. Environmental assessment of Lake Taiping (Anhui Province) based on a phytoplankton community analysis. J Lake Sci, 2014, 26: 939-947. DOI : 10.18307/2014.0617. [王俊莉, 刘冬燕, 古滨河等. 基于浮 游植物群落的安徽太平湖水环境生态评价. 湖泊科学, 2014, 26: 939-947.]

[35] Shen X, Hong DH, Tang YF et al. Ecologic environment of Luoma Lake and protection measures. Water Resources Protection, 2013, 29: 39-43. [ 申霞, 洪大林, 谈永锋等. 骆马湖生态环境现状及其保护措施. 水资源保护, 2013, 29: 39-43.]

[36] Schmidt A. Main characteristics of the phytoplankton of the Southern Hungarian section of the River Danube. Hydrobiologia, 1994, 289: 97-108. DOI: 10.1007/BF00007412.

[37] Wehr JD, Descy JP. Use of phytoplankton in large river management. Journal of Phycology, 2010, 34: 741-749. DOI: 10. 1046/j.1529-8817.1998.340741.x.

[38 ] Meng SL, Chen JC, Hu GD. Phytoplankton community characteristics and its eco-assessment on water quality in Lihu Lake, Taihu Lake. Resources and Environment in the Yangtze Basin, 2010, 19: 30. [孟顺龙, 陈家长, 胡庚东等. 太湖 蟙湖浮游植物群落特征及其对水质的评价. 长江流域资源与环境, 2010, 19: 30.] 